\title{
Assessment method of accessibility conditions: how to make public buildings accessible?
}

\author{
Isabela Fernandes Andrade e Vera Helena Moro Bins Ely ${ }^{\mathrm{a}}$ \\ a PósARQ, Course of Architecture and Urbanism, UFSC
}

\begin{abstract}
The enforcement of accessibility today has faced several difficulties, such as intervention in historic buildings that now house public services and cultural activities, such as town halls, museums and theaters and should allow access, on equal terms to all people. The paper presents the application of a method for evaluating the spatial accessibility conditions and their results. For this, we sought to support the theoretical foundation about the main issue involved and legislation. From the method used - guided walks - it was possible to identify the main barriers to accessibility in historic buildings. From the identified barriers, possible solutions are presented according to the four components of accessibility: spatial orientation, displacement, use and communication. It is hoped also that the knowledge gained in this research contributes to an improvement of accessibility legislation in relation to the listed items.
\end{abstract}

Keywords: spatial accessibility; impaired people; method; public buildings; historic heritage

\section{Introduction}

From the publication of Decree $\mathrm{N}^{\circ} 5296 / 2004$ [3] public agencies are seeking alternatives to allow that all buildings reach the existing prerogatives in ABNT NBR 9050/2004 [1], ie, allow all spaces are accessible. Decree $\mathrm{N}^{\mathrm{o}} 5.296 / 2004$ [3] determined deadline to June 2007 for the buildings of public use would ensure the accessibility, which can be defined as a condition of access to and use everywhere, regardless of the physiological condition of the individual.

The Brazilian reality shows that there are now 24.5 million impaired people. It is worth noting that of people with some limitation, temporary or not, such as pregnant women or baby strollers. In addition, there is an increasing elderly population in which, over the years, usually has several limitations in performing activities due to the natural aging process.

This work aims to identify, from a method, the problems of accessibility existing in historic buildings and, from that, make the proposition of solutions to ensure access to and use of space for all people. According to Andrade and Bins Ely [2], both preservation and the adequacy of the technical parameters of accessibility of historic heritage is of fundamental importance, since "[...] many of these buildings now house public services and cultural activities, as halls and museums."

For the classification of problems identified from the method adopted, we used the spatial components of accessibility, defined by Bins Ely, Dischinger and Piardi [5].

\section{Spatial accessibility}

Accessibility, in architecture, goes beyond the spaces that can be used by all persons on an equivalent basis. Dischinger, Bins Ely and Piardi [5] define that "spatial acessibility is much more than being able to achieve a desired place. It is also necessary that the site allows the user to understand their function, their organization and spatial relationships, as well as participate in activities that occur there. "The authors argue that these actions must be taken with safety, comfort and independence. 
In order to guide the actions of assessment and inspection of public buildings, Bins Ely, Dischinger and Piardi [5] defined the components of spatial acessibility in four categories: spatial orientation, communication, displacement and use. According to the authors, "each component consists of a set of guidelines that define the spatial characteristics to allow accessibility to public buildings and minimize possible restrictions."

The spatial orientation is linked to the understanding of space, thus allowing users to recognize the identity of function space and define their strategies for use and displacement. The terms of direction depends on the settings of architectural and additional existing information media, as well as conditions of the individual to make decisions and act.

The communication refers to the possibilities of interpersonal exchange of information, or exchange of information through the use of assistive technology devices, enabling access, understanding and use of existing activities.

Displacement refers to the conditions of displacement along the horizontal and vertical routes independently, safe and comfortable, uninterrupted and free of barriers.

The use is obtained through the possibility of participation of each and every individual in the activities and can use all environments and equipment.

In order to obtain spatial accessibility, it is necessary to meet the components in its entirety. It should be noted that the absence of one of these components results in a commitment of others.

\section{Method}

In order to identify the main information about facilities and difficulties observed in spatial orientation, communication, movement and use of equipment / furniture for people in historic buildings, it was decided to use the method called guided walks, developed by Dischinger [ 6].

The method consists of guided visits to sites that was assessed, with people who are restricted in the use of space or some characteristic that is relevant to the search. Initially, are established the activities that interviewee must comply, and along the route used by him, his behavior is observed and made inquiries about the decision-making. As Dischinger [6], the researcher should not help or lead, can interfere only in situations that present risks to the respondent. All the talk should be recorded for later transcription, and with the help of the technique of photography, the main facts must be recorded.

\subsection{Sample characterization}

In order to obtain information about the conditions of accessibility to public buildings adopted for this study, we chose to conduct tours with individuals who have different disabilities, as a person with crutches or in wheelchairs, or people without disabilities, but could be spatial restricted, as a mother with a stroller and elderly. We sought to identify those that present problems for the four components of accessibility: spatial orientation - blind and person who don't knows the place; communication - deaf and blind; displacement - people in wheelchairs, people with crutches and a mother with stroller; use of space - the elderly, people in wheelchairs, people with crutches, a mother with stroller and children. The tours took place in two historic buildings that now serve public partitions - City Hall and Department of Culture - the city of Pelotas / RS / Brazil.

\subsection{Preparation of experiment}

Initially set the scripts of activities that should be developed in buildings, in accordance with the different activities performed in them by the public, such as visiting the art show, using the toilets, visit the museum collection and ask for information in both buildings on something relevant to space.

During the tours, in addition to the observations during the course of the activities were also asked questions regarding their perception of the environment and decision making (behavior and action), complementing the method. At the end of the tour were made the following questions: what are the facilities found along the way? what are the difficulties encountered along the way? you use road signs to guide you? what you liked / found interesting about this building? what you do not like / not found interesting about this building?

The tours lasted an average of 50 minutes each and occurred in the morning shift (hours of operation of the 
Secretariat of Culture and the Municipality). The determination of days and times was done according to the availability of respondents.

Initially there were the tours with a person with crutches, the mother with the stroller, the blind, the elderly and the person who didn't know the location in the Department of Culture. To complement some necessary data, we chose to make the other rides - with the person in a wheelchair, with the children and the deaf - in City Hall. The problems identified in both buildings were similar, and because of this, the same tours were not conducted in the two buildings.

\section{Results}

The following tables present the main problems encountered for each individual from the guided walks on the four components of spatial accessibility - spatial orientation, communication, displacement and use and according to the environments visited during the main application of this method. The results are presented in two tables: the first (Table 1 and 2) illustrates the tours conducted in the Department of Culture with person with crutches, the mother with a stroller, the elderly, the blind person and person that's didn't knowledge of the site. The second (Table 3) indicates the results obtained when applying the method in City Hall with the deaf, the person in a wheelchair and children.

Table 1

Results of guided walks in Department of Culture.

\begin{tabular}{|c|c|c|c|c|c|c|}
\hline \multicolumn{7}{|c|}{ SUMMARY TABLE OF GUIDED WALKS | DEPARTMENT OF CULTURE } \\
\hline \multirow{2}{*}{ INDIVIDUAL } & \multirow{2}{*}{$\begin{array}{c}\text { MAIN } \\
\text { ACTIVITIES }\end{array}$} & \multicolumn{5}{|c|}{ ACCESSIBILITY COMPONENT } \\
\hline & & Spatial Orientation & 1 & Communicatio & ג Displacement & tก Use \\
\hline \multirow{4}{*}{ are } & $\begin{array}{l}\text { ACCESS TO } \\
\text { BUILDING }\end{array}$ & $\begin{array}{l}\text { - difficulty of locating the } \\
\text { building by the absence of } \\
\text { signposts }\end{array}$ & & & $\begin{array}{l}\text { - entry complicated by the } \\
\text { presence of steps }\end{array}$ & $\begin{array}{l}\text { - absence of a handrail to climb } \\
\text { the steps of the main access }\end{array}$ \\
\hline & $\begin{array}{l}\text { ENVIRONMENTS } \\
\text { VISITED }\end{array}$ & $\begin{array}{l}\text { - difficult to find the art show, } \\
\text { the bathrooms and the design } \\
\text { sector }\end{array}$ & & & $\begin{array}{l}\text { - little light in the exhibition } \\
\text { halls }\end{array}$ & - the bathroom door close \\
\hline & CIRCULATION & $\begin{array}{l}\text { - difficulty in identifying the } \\
\text { vertical circulations by lack of } \\
\text { signaling }\end{array}$ & & & $\begin{array}{l}\text { - main stairs is tiring - unique } \\
\text { bid; spiral service staircase, } \\
\text { dark space }\end{array}$ & $\begin{array}{l}\text { - lack of handrails on the stairs } \\
\text { service }\end{array}$ \\
\hline & $\begin{array}{l}\text { OUT OF THE } \\
\text { BUILDING }\end{array}$ & $\begin{array}{l}\text { - absence of signs telling you } \\
\text { where the exit was called for } \\
\text { verbal information }\end{array}$ & & & $\begin{array}{l}\text { - exit hampered by the } \\
\text { presence of steps }\end{array}$ & $\begin{array}{l}\text { - absence of a handrail down } \\
\text { thesteps to the main access }\end{array}$ \\
\hline \multirow{4}{*}{0100} & $\begin{array}{l}\text { ACCESS TO } \\
\text { BUILDING }\end{array}$ & $\begin{array}{l}\text { - had to climb stairs, as it was } \\
\text { informed by the receptionist } \\
\text { who was the only access }\end{array}$ & & & $\begin{array}{l}\text { - absence of the main access } \\
\text { ramp-had to climb the steps to } \\
\text { enter }\end{array}$ & \\
\hline & $\begin{array}{l}\text { ENVIRONMENTS } \\
\text { VISITED }\end{array}$ & $\begin{array}{l}\text { - had trouble finding } \\
\text { environments due to lack of } \\
\text { signaling }\end{array}$ & & & $\begin{array}{l}\text { - will close the doors - one leaf } \\
\text { was closed, dark environment } \\
\text { in showrooms }\end{array}$ & $\begin{array}{l}\text { - lack of comfort station; } \\
\text { difficulty in opening the doors } \\
\text { toenter the environment }\end{array}$ \\
\hline & CIRCULATION & $\begin{array}{l}\text { - difficulty in identifying the } \\
\text { vertical circulations by lack of } \\
\text { signaling }\end{array}$ & & & $\begin{array}{l}\text { - no lift/ ramp access to the 2nd } \\
\text { floor }\end{array}$ & \\
\hline & $\begin{array}{l}\text { OUT OF THE } \\
\text { BUILDING }\end{array}$ & $\begin{array}{l}\text { - to ask for help so that the side } \\
\text { door (with ramp) was opened } \\
\text { for use }\end{array}$ & & & $\begin{array}{l}\text { - used good ramp inclination to } \\
\text { leave the building }\end{array}$ & $\begin{array}{l}\text { - ramp has no handrails on } \\
\text { both sides or railing }\end{array}$ \\
\hline
\end{tabular}


Table 2

Results of guided walks in Department of Culture - continuation.

\section{SUMMARY TABLE OF GUIDED WALKS | DEPARTMENT OF CULTURE}

\begin{tabular}{|c|c|c|c|c|c|}
\hline \multirow{2}{*}{ INDIVIDUAL } & \multirow{2}{*}{$\begin{array}{c}\text { MAIN } \\
\text { ACTIVITIES }\end{array}$} & \multicolumn{4}{|c|}{ ACCESSIBILITY COMPONENT } \\
\hline & & Spatial Orientation & 1 Communicatio & $\lambda$ Displacement & In Use \\
\hline \multirow{4}{*}{ की } & $\begin{array}{l}\text { ACCESS TO } \\
\text { BUILDING }\end{array}$ & & & & \\
\hline & $\begin{array}{l}\text { ENVIRONMENTS } \\
\text { VISITED }\end{array}$ & $\begin{array}{l}\text { - absence of signs indicating } \\
\text { the environments, requiring } \\
\text { verbal information asked }\end{array}$ & & $\begin{array}{l}\text { - depending on the slippery } \\
\text { wax }\end{array}$ & $\begin{array}{l}\text { - commented that the fat or } \\
\text { obese person would not close } \\
\text { the stall door of the toilet bowl }\end{array}$ \\
\hline & CIRCULATION & $\begin{array}{l}\text { - difficulty locating the vertical } \\
\text { circulation - was lost in the } \\
\text { museum }\end{array}$ & & $\begin{array}{l}\text { - difficulty to the up / down by } \\
\text { poor lighting }\end{array}$ & $\begin{array}{l}\text { - used the handrail to climb the } \\
\text { main staircase, the service has } \\
\text { no handrail }\end{array}$ \\
\hline & $\begin{array}{l}\text { OUT OF THE } \\
\text { BUILDING }\end{array}$ & $\begin{array}{l}\text { complained that lacked } \\
\text { indication of output, even } \\
\text { being a publicbuilding }\end{array}$ & & $\begin{array}{l}\text { - although he said he had no } \\
\text { trouble, had to lean against the } \\
\text { wall }\end{array}$ & \\
\hline \multirow{4}{*}{$\frac{6}{58}$} & $\begin{array}{l}\text { ACCESS TO } \\
\text { BUILDING }\end{array}$ & $\begin{array}{l}\text { - difficult to find access to the } \\
\text { building }\end{array}$ & $\begin{array}{l}\text { - there is no booklet with the } \\
\text { history of the building in } \\
\text { Braille }\end{array}$ & & \\
\hline & $\begin{array}{l}\text { ENVIRONMENTS } \\
\text { VISITED }\end{array}$ & $\begin{array}{l}\text { - difficulty locating the rooms, } \\
\text { asking for information along } \\
\text { the way }\end{array}$ & $\begin{array}{l}\text { - lack of explanation in Braille } \\
\text { or spoken in the exhibition } \\
\text { explaining the works of art }\end{array}$ & $\begin{array}{l}\text { - guide indicating the absence } \\
\text { of floor doors, barrier (glass) in } \\
\text { the middle of the bathroom }\end{array}$ & $\begin{array}{l}\text { - had difficulty locating boxes } \\
\text { in the bathroom and shut the } \\
\text { door }\end{array}$ \\
\hline & CIRCULATION & $\begin{array}{l}\text { - absence of tactile floor at the } \\
\text { beginning and end of stairs, } \\
\text { lack of information in Braille }\end{array}$ & $\begin{array}{l}\text {-absence of indicated braille in } \\
\text { circulation and access }\end{array}$ & $\begin{array}{l}\text { - rungs of the ladder of service } \\
\text { high and 'dangerous'. Main } \\
\text { steps of the ladder close }\end{array}$ & \\
\hline & $\begin{array}{l}\text { OUT OF THE } \\
\text { BUILDING }\end{array}$ & $\begin{array}{l}\text { - was guided by the noise from } \\
\text { the street to find the port }\end{array}$ & & $\begin{array}{l}\text { - needed the aid of a cane to } \\
\text { identify the steps }\end{array}$ & $\begin{array}{l}\text { - had to lean against the wall } \\
\text { due to lack of handrail }\end{array}$ \\
\hline \multirow{4}{*}{50} & $\begin{array}{l}\text { ACCESS TO } \\
\text { BUILDING }\end{array}$ & $\begin{array}{l}\text { - difficult to identify and locate } \\
\text { the building access }\end{array}$ & & & \\
\hline & $\begin{array}{l}\text { ENVIRONMENTS } \\
\text { VISITED }\end{array}$ & $\begin{array}{l}\text { - absence of signposts in the } \\
\text { bathroom - male and female, } \\
\text { absence of plates with sections }\end{array}$ & & & $\begin{array}{l}\text { - difficulty in using the tap, the } \\
\text { door handle down time }\end{array}$ \\
\hline & CIRCULATION & & & -service stairs in dim lighting & $\begin{array}{l}\text { - absence of a handrail on one } \\
\text { side of the main stairs }\end{array}$ \\
\hline & $\begin{array}{l}\text { OUT OF THE } \\
\text { BUILDING }\end{array}$ & $\begin{array}{l}\text { - absence of signs indicating } \\
\text { the exit of the building, he felt } \\
\text { lost }\end{array}$ & & & \\
\hline
\end{tabular}


Table 3 .

Results of guided walks in City Hall.

\begin{tabular}{|c|c|c|c|c|c|}
\hline \multicolumn{6}{|c|}{ SUMMARY TABLE OF GUIDED WALKS | CITY HALL } \\
\hline \multirow[b]{2}{*}{ INDIVIDUAL } & \multirow{2}{*}{$\begin{array}{c}\text { MAIN } \\
\text { ACTIVITIES }\end{array}$} & \multicolumn{4}{|c|}{ ACCESSIBILITY COMPONENT } \\
\hline & & Spatial Orientation & $1 /$ Communicatio & $\lambda$ Displacement & t-1 Use \\
\hline \multirow{4}{*}{5} & $\begin{array}{l}\text { ACCESS TO } \\
\text { BUILDING }\end{array}$ & & $\begin{array}{l}\text {-absence of pounds interpreter } \\
\text { to communicate with the } \\
\text { respondent }\end{array}$ & & \\
\hline & $\begin{array}{l}\text { ENVIRONMENTS } \\
\text { VISITED }\end{array}$ & $\begin{array}{l}\text { - absence of signposts in the } \\
\text { bathroom the 1st floor and in } \\
\text { different sectors }\end{array}$ & $\begin{array}{l}\text { - has requested information in } \\
\text { writing; difficulty in } \\
\text { understanding informations }\end{array}$ & $\begin{array}{l}\text { - step at the entrance of the } \\
\text { bathroom is not signaled, } \\
\text { causing a stumbling }\end{array}$ & \\
\hline & CIRCULATION & $\begin{array}{l}\text { - difficulty locating the vertical } \\
\text { circulation, was lost trying to } \\
\text { find the museum }\end{array}$ & $\begin{array}{l}\text { - written information needed } \\
\text { to identify the location of the } \\
\text { elevator }\end{array}$ & & \\
\hline & $\begin{array}{l}\text { OUT OF THE } \\
\text { BUILDING }\end{array}$ & $\begin{array}{l}\text { - difficult to identify the exit of } \\
\text { the building due to lack of } \\
\text { signposts }\end{array}$ & & & \\
\hline \multirow{4}{*}{$8)^{3}$} & $\begin{array}{l}\text { ACCESS TO } \\
\text { BUILDING }\end{array}$ & $\begin{array}{l}\text {-absence of visual information } \\
\text { indicating the entrance for } \\
\text { people withdisabilities }\end{array}$ & & $\begin{array}{l}\text { - lack of ramps and / or } \\
\text { electromechanical equipment } \\
\text { for climbing }\end{array}$ & \\
\hline & $\begin{array}{l}\text { ENVIRONMENTS } \\
\text { VISITED }\end{array}$ & $\begin{array}{l}\text { - absence of signs indicating } \\
\text { the bathrooms and other } \\
\text { sectors }\end{array}$ & & $\begin{array}{l}\text { - ranging from small internal } \\
\text { doors, } 12 \mathrm{~cm} \text { step at the } \\
\text { entrance to the bathroom }\end{array}$ & $\begin{array}{l}\text { - counter service too high and } \\
\text { no room for approximation } \\
\text { chair }\end{array}$ \\
\hline & CIRCULATION & & & $\begin{array}{l}\text { - will lift less than } 80 \mathrm{~cm} \mathrm{did} \mathrm{not} \\
\text { allow the entry of the chair }\end{array}$ & $\begin{array}{l}\text { - scattered objects did not } \\
\text { allow the interviewee came to } \\
\text { the bathroom }\end{array}$ \\
\hline & $\begin{array}{l}\text { OUT OF THE } \\
\text { BUILDING }\end{array}$ & & & $\begin{array}{l}\text {-needed the help of staff, again } \\
\text { todown it 'arms' }\end{array}$ & \\
\hline \multirow{4}{*}{$\frac{9}{d b}$} & $\begin{array}{l}\text { ACCESS TO } \\
\text { BUILDING }\end{array}$ & & & $\begin{array}{l}\text { - mirror the steps too high, } \\
\text { hindering the passage of the } \\
\text { children }\end{array}$ & \\
\hline & $\begin{array}{l}\text { ENVIRONMENTS } \\
\text { VISITED }\end{array}$ & $\begin{array}{l}\text { - absence of signs indicating } \\
\text { the bathrooms and other } \\
\text { sectors }\end{array}$ & & & $\begin{array}{l}\text { - height of the seats is high for } \\
\text { children; time high attendance } \\
\text { of the window }\end{array}$ \\
\hline & CIRCULATION & $\begin{array}{l}\text { - absence of visual information } \\
\text { in the output indicating the } \\
\text { number of the elevator floor }\end{array}$ & & $\begin{array}{l}\text { - tripping on the step formed } \\
\text { between elevator and floor of } \\
\text { the 1st flloor }\end{array}$ & $\begin{array}{l}\text { - lack of handrails on the stairs, } \\
\text { large, caused insecurity, the } \\
\text { elevator call buttons, urinals } \\
\text { and shelves of the museum of } \\
\text { mayors in high altitude }\end{array}$ \\
\hline & $\begin{array}{l}\text { OUT OF THE } \\
\text { BUILDING }\end{array}$ & & & & $\begin{array}{l}\text { - inadequate handrail height } \\
\text { did not allow children tolean }\end{array}$ \\
\hline
\end{tabular}

Tables with the results of guided walks show that all respondents had difficulties in relation to spatial orientation, displacement and use. The highest incidence of problems occurred in the spatial orientation, then the component displacement. The communication component was recorded only to the blind and deaf individuals.
An important issue identified through the analysis of the data of Table 1 indicates that all users had difficulty finding the exit of the building (orientation), except the blind, who managed to identify it through the street noise. However, it complained about the lack of tactile floor.

The problems in spatial orientation component not only affect people with disabilities but also people who 
don't know the place. An example was the difficulty that most respondents had to identify both the buildings and the different indoor environments. This is due to the absence of visual and tactile information media.

Since the problems facing the displacement were offset, mainly, by some individuals with limited mobility such as wheelchair and people with crutches, but also by people without disabilities. The mother with the stroller has a restriction of the environment in relation to the displacement when cannot access the 2nd floor of the buildings studied.

All people, regardless of their capabilities and limitations, presented difficulties in relation to the component use. Those most affected are in wheelchairs, people with crutches and children.

The communication component is not very evident in the overall results because it affects mainly people who are deaf and blind. One example is the difficulty the blind person had to understand what works represented in art galleries, as there was no information in Braille or spoken text.

One can see that the individual most affected when the four components are not considered in different spaces is the blind, followed by the individual in a wheelchair and people with crutches.

\section{Discussion}

From the problems identified by the method described above were organized 24 frames contextualizing solutions to case studies. In the first column shows the problem identified and the people who, in the absence of solution, are affected. The second is indicated if the problem is approached by some rule or law (ABNT NBR 9050/2004, ABNT NBR 9077/2001, ABNT NBR 13994/2000 and Federal Decree-Law 5296/2004) or not and, when approached, which the rule / law recommends. The fourth and last column shows the possible solutions to resolve conflict situations.

It presents an example of the solution proposed for just one of spatial components of accessibility (Table 4). This means that only one solution are shown for a total of seventy-nine problems identified.

Table 4.

Exemple of solution proposed to resolve the identified problem.

IDENTIFIED PROBLEMS AND ALTERNATIVE SOLUTIONS IN RELATION TO SPATIAL ORIENTATION

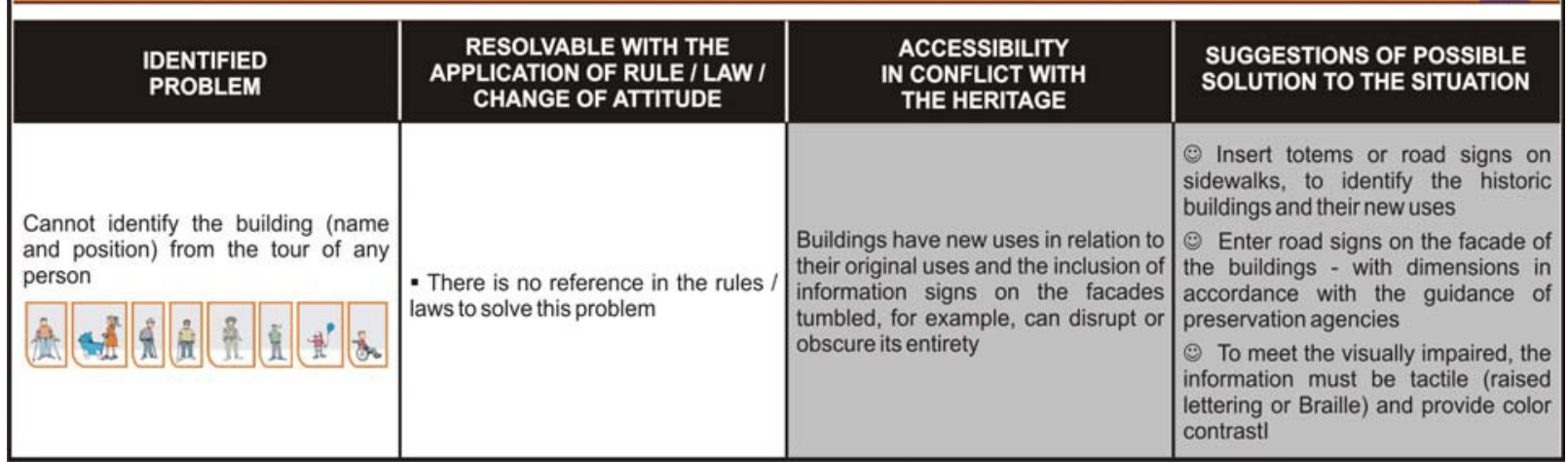




\section{Conclusion}

The method called guided walks was key to knowledge of the location and identification of problems faced by people when some of the components of accessibility is not considered in the spatial solutions adopted, since it is possible to combine behavioral observations and interviews about the attributes of space. From the application of the method, it was possible to propose some spatial solutions to be adopted to solve the problems identified.

The study conducted showed that despite the great advances that have occurred in relation to social awareness, people with disabilities and who suffer restrictions are still excluded from common activities such as access to public and cultural buildings. And, even the legal mechanisms that have been created in recent years, all of great importance, are not applied as they should and with the necessary scope.

The accessibility application requires a deep understanding of the limitations coming from the different weaknesses that can reach people. Allied to this, the absence of design guidelines to promote accessibility in historic buildings has forced practitioners to seek individual solutions in different manuals and own NBR 9050/2004, which resulted in actions that only partial and ineffective.

In relation to the problems identified, can be seen that in $48 \%$ there is a conflict between the implementation of accessibility and preservation of heritage. In the other $52 \%$ there is no conflict with the assets, of which $42 \%$ of them could be resolved if the solutions envisaged in the adopted standards. Only $10 \%$ of the problems that do not generate conflict between the issues involved are not identified in standard solutions.

From this, it is suggested the formulation of guidelines to assist decision-making in specific situations, such as those in which the parameters of accessibility conflicts with the conservation and contribute to the improvement of accessibility in the legislation listed items.

\section{References}

[1] ABNT NBR 9050. Acessibilidade de pessoas portadoras de deficiências a edificações, espaço, mobiliário e equipamentos urbanos. Rio de Janeiro, ABNT, 2004.

[2] ANDRADE, Isabela Fernandes; BINS-ELY, Vera Helena Moro. Acessibilidade em edificações históricas: avaliando o caso de Pelotas. Ação Ergonômica, vol. 5, 2010.

[3] BRASIL. Decreto $\mathrm{n}^{0} 5.296$ de 2 de dezembro de 2004 BRASIL, 2004.

[4] CIF: Classificação Internacional de Funcionalidade, Incapacidade e Saúde / [Centro Colaborador da Organização Mundial da Saúde para a Família de Classificações Internacionais em Português, org.; coordenação da tradução Cássia Maria Buchalla]. - 1. ed., 1. reimpre. - São Paulo: Editora da Universidade de São Paulo, 2008. 325p.

[5] DISCHINGER, Marta; BINS ELY. Vera Helena Moro; PIARDI, Sonia. Promovendo a acessibilidade nos edifícios públicos: Programa de Fiscalização do Ministério Público de Santa Catarina. Trabalho em andamento. Florianópolis, 2009.

[6] DISCHINGER, Marta. Designing for all senses: Accessible spaces for visually impaired citizens. Thesis for the degree of doctor of philosophy. Sweden, 2000. 260p.

[7] GIBSON, James. The senses considered as perceptual systems. Boston: Houghtan Mifflin Company, 1966. 